\title{
The Results of Nurses' Increasing Emotional Intelligence and Resilience
}

\author{
Hemşirelerde Duygusal Zekâ ve Psikolojik Dayanıklıık Artışının Yansımaları
}

\author{
Olcay ÇAM, ${ }^{1}$ Ayşe BÜYÜKBAYRAM ${ }^{2}$
}

\begin{abstract}
SUMMARY
Resilience is people's ability to pull themselves together before difficult life experiences or their ability to cope with crises or disasters successfully. It is particularly important for nurses to improve their resilience since they face many traumatic situations in their stressful professional lives. It is important to identify the risks that affect resilience to be able to improve it and be informed about protective factors. Resilience interacts with emotional intelligence, one of its protective factors. The results of this interaction are the improvement of professional nursing approaches and the profession itself, professional patient care and patient satisfaction, reduced burnout and resignations, and increased professional and life satisfaction. The improvement of emotional intelligence skills is important since it increases nurses' individual and social resilience and improves their professional and life outcomes. This literature review explains nurses' resilience and the importance of emotional intelligence skills in improving resilience, the interaction between emotional intelligence skills and resilience, the professional results of this interaction, emotional intelligence skills and the factors that affect resilience.
\end{abstract}

Keywords: Emotional intelligence; nurse; resilience.

\begin{abstract}
ÖZET
Psikolojik dayanıklılık, zor yaşamsal tecrübeler karsısında kişinin kendisini toparlama gücü veya değişimin, felaketlerin başarılı biçimde üstesinden gelme yeteneğidir. Özellikle sıkıntılı, stresli iş yaşamında, birçok travmatik durumla karşılaşan hemşireler için psikolojik dayanıkııı̆ın geliştirilmesi önemlidir. Psikolojik dayanıklılığı geliştirmek için dayanıklılı̆ı etkileyen risklerin tanınması ve koruyucu faktörler bilinmelidir. Psikolojik dayanıkılık; koruyucu faktörlerinden olan duygusal zekâ becerileriyle etkileşim içindedir. Bu etkileşimin yansımaları; profesyonel hemşirelik anlayışı ve mesleğin gelişmesi, profesyonel hasta bakım hizmetlerinin yapılması ve hasta memnuniyeti, hemşirelerin tükenmişlik duygularının ve işten ayrılmalarının azalması, iş ve yaşam doyumlarının artması şeklindedir. Bu nedenle duygusal zekâ becerilerinin geliştirilmesi; hemşirelerde bireysel ve sosyal olarak psikolojik dayanıklılı̆ın artması ve olumlu iş ve yaşam çıktıları açısından önemlidir. Bu derlemede hemşirelerde psikolojik dayanıklılık ve psikolojik dayanıklılığı geliştirmede duygusal zekâ becerilerinin önemi, duygusal zekâ becerilerinin psikolojik dayanıklılıkla etkileşimi ve mesleki yansımaları, duygusal zekâ becerileri ve psikolojik dayanıklılığ etkileyen etmenler açıklanmaktadır.
\end{abstract}

Anahtar sözcükler: Duygusal zeka; hemşire; psikolojik dayanıkllik.

\section{Introduction}

Resilience is people's ability to adapt and pull themselves together or their ability to overcome crises or disasters. It refers to people's capacity to deal successfully with major stressors in life, including traumas, threats, tragedies, family or relationship problems, serious health problems and workplace or financial problems. ${ }^{[1-6]}$

Nurses directly or indirectly face many traumatic situations due to the stressful and traumatic situations while caring for patients in difficulty. Nurses experience burnout, low satisfaction in professional and social life and resign in early phases of their careers for many reasons, including unrealistic professional expectations, insufficient emotional and stress-

'Department of Mental Health and Psychiatric Nursing, Ege University Faculty of Nursing, Izmir

${ }^{2}$ Department of Mental Health and Psychiatric Nursing, Izmir Kâtip Çelebi University Faculty of Healt Science, Izmir

Correspondence (illetişim): Dr. Ayşe BÜYÜKBAYRAM.

e-mail (e-posta): abayram35@gmail.com

Psikiyatri Hemşireliği Dergisi 2015;6(3):130-136

Journal of Psychiatric Nursing 2015;6(3):130-136

Doi: $10.5505 /$ phd.2015.96729

Submitted (Gelis tarihi): 01.07.2014 Accepted (Kabul tarihi): 10.09.2015 related coping skills, a lack of positive expectations and insufficient support from their colleagues and teams. ${ }^{[4,7-10]}$

The relevant studies have found that nurses' resilience is important since it reduces resignations and helps them to manage the high levels of stress in health sector found by the studies on professional and life satisfaction. ${ }^{[4,6,9-11]}$ Emotional intelligence directly influences resilience. ${ }^{[7-9,12-18]}$

This literature review aimed to explain resilience and the importance of emotional intelligence skills in improving resilience, the interaction between emotional intelligence and its professional outcomes, and the factors that affect emotional intelligence skills and resilience.

With this purpose, the author screened the studies conducted between the years 2000 and 2015 using Microsoft Academic Research, Wiley On-line Library, PubMed, Research Gate, Science Direct, Google Scholar, Ulakbim and the National Center for Theses data bases. The author did the screening in English and Turkish, using the keywords: resilience, emotional intelligence, emotional intelligence and resilience, emotional intelligence and resilience in nurses, emotional intelligence skills training and resilience development. After the screening, the author included the studies of emotional intelligence skills and resilience that were con- 
ducted with nurses and studies of the relation between these two concepts.

\section{Emotional Intelligence and Resilience in Nurses}

Nurses face many risk factors in their professional lives, and they are supposed to provide quality patient care to patients. Thus, it is important for them to be informed about their own risk factors along with familial, social and profes- sional protective factors. ${ }^{[4,7-10,13,19-23]}$ The protective factors that affect nurses' resilience are:

Internal factors: the personal protective factors are emotional intelligence skills, including optimism, cognitive flexibility, altruism, conscientiousness, creativity, being extroverted, openness, autonomy, sticking to ethical and moral values, a sense of humor, trust, adaptive coping strategies, taking

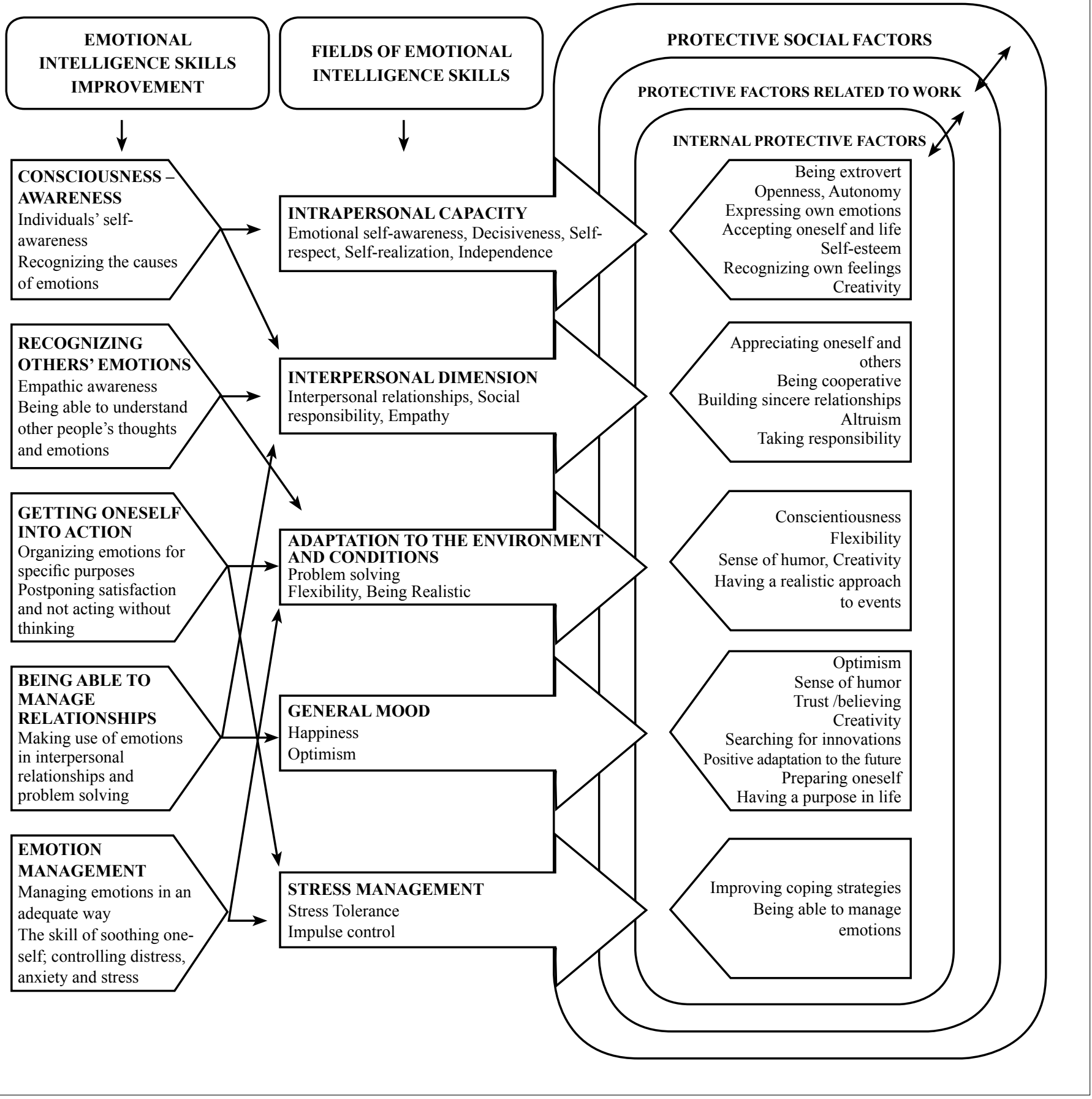

Figure 1. The relation between emotional intelligence skills and resilience, and the interaction between emotional intelligence skills and the emotional intelligence skills program. 
resilient persons as role models, accepting oneself and life, appreciating oneself, realistic thought, positive thoughts and personality, being emotionally aware, expressing and managing emotions. ${ }^{[4,6,13,22,24,25]}$ Protective factors related to the $\mathrm{fu}^{-}$ ture include searching for innovations and adapting to them, and having plans for and positive expectations. ${ }^{[21,25]}$

External factors: Social protective factors include positive family relationships, supportive social communication networks, and social resources. Professional protective factors include professional experience, professional satisfaction, being informed, sharing knowledge and skills, being adaptive, positive attitudes towards work, being supported by colleagues, teams and consultants, sharing problems with colleagues, recognizing stressors and finding solutions, creating a balance between professional and social life, building sincere relationships with colleagues, sharing personal experiences, trust, congratulating and appreciating colleagues' success. . $^{[4,6,7,21,24,25]}$

Specifically, emotional intelligence skills are the abilities which help people understand themselves and others, to be aware of their emotions and those of the others, build relationships with people, find flexible, realistic and effective solutions to problematic situations, adapt and cope with unresolvable problems. These skills increase people's adaptive ability, which improves their resilience, their ability to overcome difficult situations, and the success and pleasure they have with life. ${ }^{[11,13,18-20,26-32]}$

Individuals with strong emotional intelligence skills and resilience are optimists, extroverts, have good social relationships, are open to new experiences, capable of adapting to changes easily, make use of effective problem solving skills, have flexible cognitive thinking, are creative and have high self-confidence and self-esteem. ${ }^{[6,9,14,16,18,33-35]}$ Figure 1 presents the relationship between the components of emotional intelligence and resilience.

An analysis of previous studies indicated that people who have improved resilience use emotional intelligence skills, and that, to improve resilience, it is necessary to use these emotional intelligence skills: "self-consciousness, knowing about oneself and being emotionally aware;"[16,20,36] "empathy, understanding other people's thoughts and emotions and being able to express this understanding;"; $[16,22]$ "managing per- sonal relationships, making use of emotions in interpersonal relationships and problem solving;", $[13,22,26]$ "motivation;"; $[19]$ "managing feelings," $[8,16,18,20,26,31]$ and "stirring oneself, being able to organize emotions for a specific purpose." ${ }^{[4,8,13,22]}$

Nurses work under difficult conditions, face many stressful situations and have a job that does not tolerate faults. Thus, it is important for them to have emotional intelligence skills since they make tough decisions in limited periods of time, use flexible and realistic and effective methods to solve problems, and work in environments that require solidarity and cooperation. ${ }^{[27,37-39]}$ These skills particularly help them deal with the problem without losing their hope in stressful situations, getting in the most adequate mood, and maintain the patient care in the best way in the most difficult situations. ${ }^{[37,38,40,41]}$ These skills also significantly affect nurses' professional satisfaction and burnout. ${ }^{[14,27,37-41]}$

\section{The Relationship between Emotional Intelligence Skills, Resilience and the Factors That Influence Them}

Emotional intelligence is a concept that primarily helps individuals understand and manage their own emotions and those of others, empathizing, increasing motivation and improving self-confidence. ${ }^{[42]}$

Bar-On described emotional intelligence as: "the sequence of personal, emotional and social competencies and skills that help an individual cope with pressure and demands in their environment."[27-29]

According to Bar-On, emotional intelligence skills have 15 sub-dimensions and five dimensions. Their dimensions are intrapersonal capacity interpersonal relations, adaptation to the environment and conditions, elements of stress management and general mood (Table 1). ${ }^{[27-29]}$

1. The Intrapersonal Capacity Dimension: Personal awareness is a people's recognition of their own inner worlds, being able to make choices, and being aware of their resources and abilities. ${ }^{[27,28]}$ People with resilience have high selfawareness. ${ }^{[33]}$ The intrapersonal capacity dimension includes five sub-dimensions:

a) Emotional Self-awareness: This is a people's awareness of their emotions, their consequences and expression. It is not

Table 1. Emotional intelligence skills in Bar-On's model

\begin{tabular}{|c|c|c|c|c|}
\hline Intrapersonal capacity & $\begin{array}{l}\text { Interpersonal } \\
\text { relationships }\end{array}$ & $\begin{array}{l}\text { Adaptation to the } \\
\text { environment and conditions }\end{array}$ & $\begin{array}{c}\text { Stress } \\
\text { management }\end{array}$ & General mood \\
\hline $\begin{array}{l}\text { Emotional self-awareness } \\
\text { Decisiveness } \\
\text { Self-respect } \\
\text { Self-realization } \\
\text { Independence }\end{array}$ & $\begin{array}{c}\text { Empathy } \\
\text { Interpersonal } \\
\text { Relationships } \\
\text { Social responsibility }\end{array}$ & $\begin{array}{l}\text { Problem solving } \\
\text { Flexibility } \\
\text { Being realistic }\end{array}$ & $\begin{array}{l}\text { Stress tolerance } \\
\text { Impulse control }\end{array}$ & $\begin{array}{l}\text { Happiness } \\
\text { Optimism }\end{array}$ \\
\hline
\end{tabular}


only about being aware of emotions, but also understanding their causes and the differences between them. ${ }^{[27,28]}$

Being aware of emotions increases resilience by helping people obtain the resources to help them cope with stress sooner and use effective coping strategies. ${ }^{[16]}$

If nurses are aware of their emotions and able to manage them, this affects their resilience ${ }^{[9]}$ and professional satisfaction. ${ }^{[15,40-43]}$ For nurses to learn about the skills that develop relationships and increase their resilience, they should be taught the skills of expressing their thoughts and emotions, ${ }^{[13,18,25]}$ which requires the use of art therapy. ${ }^{[18]}$

b) Decisiveness: Decisiveness is the ability to express one's emotions, beliefs and thoughts and to defend one's rights without being destructive. ${ }^{[27,28]}$

To be able to improve resilience, people should resolve problems decisively. ${ }^{[4]}$ Thus, nurses should not compensate for their professional identity and be decisive. ${ }^{[4,8]}$

c) Self-respect: Self-respect is a person's feeling good inside, self-respect and self-acceptance. Accepting oneself is the ability to accept one's positive and negative sides, limitations and abilities. ${ }^{[27,28]} \mathrm{It}$ is one of the important indicators of mental health and essential to motivation. ${ }^{[34,35]}$

People with strong self-esteem do not feel worthless in negative situations. They have self-control, are able to evaluate situations objectively, and look for help when they are stressed. They learn from results, regard negative situations as an opportunity to improve themselves and fortify themselves for the future. They are satisfied with their lives. ${ }^{[27,28,34,35]}$

To improve nurses' resilience, workplaces strategies addressed to developing optimism, initiative, self-esteem and awareness of the past, present and future need to be developed. ${ }^{[13]}$ Individual and group counseling focused on improving self-esteem should also be provided. ${ }^{[34]}$

d) Self-realization: This means identifying one's potential. The result of this element of emotional intelligence is living a full and meaningful life. The continuous improvement of a person's abilities is a never-ending, dynamic process. ${ }^{[27,28]} \mathrm{Peo-}$ ple who are aware of their self-efficacy can realize themselves. These people's ability to overcome challenges, adapt, solve problems and reduce stress influences their resilience. ${ }^{[12,43]}$

Nurses' self-efficacy, self-control, hopes, social sufficiency and coping skills affect their resilience. ${ }^{[10,15]}$ In order to increase nurses' self-efficacy, educational strategies based on clinical knowledge and skills should be used. ${ }^{[11,12]}$

e) Independence: Independence is people's controlling and orienting their own thoughts and acts. When people are autonomous, they become aware of their behavior and actions, feel valuable and have individual responsibility. ${ }^{[27,28]}$
The relevant studies report that individuals who have resilience have more control over their behavior, believe that their efforts will bring them more achievement, have social efficacy, individual responsibilities and high self-control. ${ }^{[33-35]}$

2. The Interpersonal Relationships Dimension: This refers to people's actions and abilities in interpersonal relations. ${ }^{[27,28]}$

a) Empathy: Empathy means understanding people's thoughts and feelings while in dialog with them and approaching them in a sensitive way. ${ }^{[27,28]}$ The skills of empathy, optimism and positive viewpoints affect resilience. ${ }^{[22]}$

b) Interpersonal Relationships: This is the skill of building and maintaining intimate relationships based on sharing and mutual satisfaction. ${ }^{[27,28]}$

People who have resilience can make friends and maintain friendships. They can also provide emotional support to their friends when needed and maintain friendships for a very long time. They have good relationships with their families and peers and have satisfactory social support. They can access social support resources when they are in a problematic situation. ${ }^{[16,22,33]}$ They feel less lonely and desperate, and perceive life as less threatening. ${ }^{[35]}$

To improve their resilience, nurses should share their experiences of and problems with resilience and use social communication networks. They should also cooperate with their teams, accept and congratulate their colleagues for their successes. ${ }^{[13,20,22,26]}$

c) Social Responsibility: This means being an effective member in a cooperative and unified social group. People with social responsibility also have social consciousness. This dimension includes doing things with and for others and supporting social rules. ${ }^{[27,28]}$

The development of nurses' resilience requires enhanced cooperation between colleagues, counselors and teams, sharing problems and finding common solutions. ${ }^{[13,20,22,26]}$

3. The Dimension of Adaptation to the Environment and the Rules: This dimension includes people's ability to cope with the demands of an environment. ${ }^{[27,28]}$

a) Problem Solving: This means identifying problems and offering effective solutions for them. The relevant studies report that this dimension is closely related with being conscientious, systematic and disciplined, and approaching problems methodically. ${ }^{[27,28]}$

To improve nurses' resilience, it is important to have the skill of describing and comprehending problems, ${ }^{[8]}$ using problem-solving guides, evaluating critical situations and using nursing's management model. ${ }^{[4]}$

b) Being Realistic: This means determining and describ- 
ing the difference between a real situation and presuppositions. ${ }^{[27,28]}$

Individuals with resilience have a more realistic approach to occurrences, and their expectations are also realistic. ${ }^{[33]}$ If individuals are able to think both realistically and positively, create new and realistic options and develop adequate behaviors based on these ideas, they will be able to cope with stress effectively. ${ }^{[34]}$

To develop nurses' resilience, it is important that nursing practices are realistic and avoid extreme emotional approaches, that nurses be confident about understanding problems, use knowledge effectively, describe and access multiple resources for problem resolution. ${ }^{[22]}$

c) Flexibility: This means adapting one's emotions, thoughts and behavior to changing situations. ${ }^{[27,28]}$ Flexibility affects resilience by improving creativity, and adaptability in stressful situations. Individuals adapt to the situation easily by managing their emotions in stressful situations, by being in a positive mood, through optimism and self-efficacy and by pulling themselves together quickly. ${ }^{[16,18,34,35]}$

To increase nurses' resilience, it is important to improve their cognitive flexibility. ${ }^{[13,22]}$ To increase cognitive flexibility; it is important to be optimistic and have positive feelings, to make sense of one's life and current situation and to develop insights and good morale. Understanding protective and risk factors, sharing emotions, asking for help ${ }^{[8,22]}$ generating alternative ideas and creativity are also important. ${ }^{[8,18,26,31]}$

4. The Stress Management Dimension: This dimension includes the skills of coping with, tolerance for and control over reactions to stress. ${ }^{[27,28]}$

a) Stress Tolerance: This means dealing with stressful and upsetting situations. People who have a high capacity for enduring stress are able to overcome problems without much difficulty in challenging situations. ${ }^{[27,28]}$

b) Impulse Control: This means resisting, postponing and controlling one's drives. People who cannot control their feelings usually cannot cope with tension, control themselves and their anger and tend to act recklessly. ${ }^{[27,28]}$

Resilience is a dynamic process. It is directly related to resilience whether people are able to control and manage their positive and negative emotions. Individuals' use of effective coping strategies influences their adaptation to traumas and difficult situations. ${ }^{[1,6,16,17,33]}$ The skill of coping with stress has a low effect on being aware of own emotions, an intermediate effect on expressing emotions, an intermediate effect on controlling emotions and a high effect on managing emotions. ${ }^{[16]}$ It also a high effect on the skill of having positive feelings. ${ }^{[16,17,20,31]}$

A study by Augusto Landa et al. (2007) found that the dimensions of emotional intelligence had a major influence in health and stress issues, nurses with high emotional intelligence built positive interpersonal relationships, increased their problem solving skills and used adequate strategies to reduce stress, ${ }^{[38]}$ and these skills affected resilience. ${ }^{[11,19]}$

For nurses to be able to use effective coping strategies, it is important that they receive continuous support from multidisciplinary teams, professional organizations, friends and family members. Training about how to cope with problems in professional life should be offered at schools and in workplaces. ${ }^{[7,10,12,25,40]}$

5. The General Mood Dimension: This dimension includes a person's satisfaction with and general perspective on life. This dimension means being optimistic and happiness with life.

a) Happiness: Happiness is the skill of being satisfied with life, with oneself and with others and being able to have fun. Happy people usually feel good, and they are also comfortable during their work hours and spare time. They make use of the opportunities created by the fun they have.

b) Optimism: Optimism is being able to see the bright side of life, and having a positive approach even in times of difficulty. ${ }^{[27,28]}$

Laughing and using a sense of humor protect the value of the individual's self, create a feeling of looking from a distance between the person and the problem, which is healthy, and creates a new perspective on the problem. Thus, the person recovers physically, emotionally, cognitively, socially and morally. ${ }^{[44]}$

Positive emotions affect people's ability to think flexibly and creatively, to find solutions, to cope with stressful situations and pull themselves together rapidly and to adapt to new situations. This gives them a more optimistic perspective on life and happiness and enhances their resilience. ${ }^{[18,20,31,34]}$

Relevant studies have found that individuals with resilience have positive emotions, thoughts and behaviors (e.g., happiness and satisfaction with life). They are optimistic, hopeful about the future and have personal goals. ${ }^{[18-20,26,31,33,45]}$

When nurses have positive feelings, this affects their resilience and reduces stress in workplace, makes professional life more productive and fun and improves the workplace atmosphere. ${ }^{[31,34,44]}$ For nurses to improve their resilience, it is important for them to develop positive viewpoints, ${ }^{[13,20]}$ and the skills of critical thought, creative thinking and a sense of humor, all three of which help with coping. ${ }^{[13,22]}$

\section{Results and Discussion}

In the study, the training programs focused on improving emotional intelligence skills were performed in multi- 
sessions, using five basic components: self-consciousness, managing emotions, getting oneself into action, empathy and relationships). ${ }^{[46-50]}$ Figure 1 presents the correlation between emotional intelligence skills and resilience as well as the interaction between emotional intelligence skills and the training program for improving these skills. The improvement of emotional intelligence skills in nurses directly influences resilience. Thus, it is important that this type of training and studies be conducted to improve these skills in nurses.

In addition, schools and workplaces should offer courses, seminars, conferences, workshops and panels about emotional abilities (e.g., awareness training and emotional intelligence skills training) and in-service programs about coping with stress, problem solving, communication techniques and teamwork. Focus group studies and cognitive-behavioral therapy practices should be conducted to analyze the factors that influence resilience. Creative expression methods including telling stories, writing poems and autobiographies and movies should also be included in seminars and conferences.

To conclude, emotional intelligence skills and resilience interact with each other. The results of this interaction for nursing are the improvement of the understanding of professional nursing and the profession itself, professional patient care and patient satisfaction, reduced burnout and resignation and increased satisfaction with professional and social life. These things will also enhance resilience.

The author believes that there is a need for further studies of emotional intelligence and resilience due to the lack of research in this field.

\section{References}

1. Basım N, Çetin F. Yetişkinler için psikolojik dayanıklılık ölçeğinin güvenilirlik ve geçerlilik çalışması. Türk Psikiyatri Dergisi 2011;22.

2. Gürgân U. Yılmazlık ölçeği (YÖ): Ölçek geliştirme, güvenirlik ve geçerlik çalışması. Ankara Üniversitesi Eğitim Bilimleri Fakültesi Özel Eğitim Dergisi 2010;11:47-62.

3. Güngörmüş K, Okanlı A, Kocabeyoğlu T. Hemşirelik öğrencilerinin algıladıkları sosyal destek ile psikolojik dayanıklılıkları arasındaki ilişki. Erişim tarihi:15.04.2014 http://www.kongre.com.tr/uhok/ detay/?uid=328bb98a-c579-48f6-86d6-0e84c8ec9859\&id=558.

4. Garcia-Dia MJ, DiNapoli JM, Garcia-Ona L, Jakubowski R, et al. Concept analysis: resilience. Arch Psychiatr Nurs 2013;27:264-70.

5. Bahadır E. Sağlıkla ilgili fakültelerde eğitime başlayan öğrencilerin psikolojik sağlamlık düzeyleri. [Yayınlanmamış yüksek lisans tezi] Ankara: Hacettepe Üniversitesi, Sağlık Bilimleri Fakültesi 2009.

6. Öz F, Bahadır Yılmaz E. Ruh sağlığının korunmasında önemli bir kavram: Psikolojik sağlamlık. Sağlık Bilimleri Fakültesi Hemşirelik Dergisi 2009;829.

7. Castleden M, McKee M, Murray V, Leonardi G. Resilience thinking in health protection. J Public Health (Oxf) 2011;33:369-77.

8. Scholes J. Coping with the professional identity crisis: is building resilience the answer? Int J Nurs Stud 2008;45:975-8.

9. Atkinson PA, Martin CR, Rankin J. Resilience revisited. J Psychiatr Ment Health Nurs 2009;16:137-45.

10. Zander M, Hutton A, King L. Coping and resilience factors in pediatric on- cology nurses. J Pediatr Oncol Nurs 2010;27:94-108.

11. Gillespie BM, Chaboyer W, Wallis M. The influence of personal characteristics on the resilience of operating room nurses: a predictor study. Int J Nurs Stud 2009;46:968-76.

12. Gillespie BM, Chaboyer W, Wallis M, Grimbeek P. Resilience in the operating room: developing and testing of a resilience model. J Adv Nurs 2007;59:427-38.

13. Margaret $M$, John B. The resilient nurse: Empowering your practice. Springer Publishing Company; 2011.

14. Warelow $P$, Edward KL. Caring as a resilient practice in mental health nursing. Int J Ment Health Nurs 2007;16:132-5.

15. Trivellasa P, Gerogiannisb V, Svarnab S. Exploring work place implications of emotional intelligence (WLEIS) in hospitals: Job satisfaction and turnover intentions. Procedia-Socialand Behavioral Sciences 2013;73:701-9.

16. Armstrong AR, Galligan RF, Critchley CR. Emotional intelligence and psychological resilience to negative life events. Personality and Individual Differences 2011;51:331-6.

17. Karreman A, Vingerhoets A. Attachment and well-being: The mediating role of emotion regulation and resilience. Personality and Individual Differences 2012;53:821-6.

18. Metzl ES, Morrell MA. The role of creativity in models of resilience: theoretical exploration and practical applications. Journal of Creativity in Mental Health 2008;3:303-18.

19. Mealer M, Jones J, Newmana J, Mcfann KK, et al. The presence of resilience is associated with a healthier psychological profile in intensive care unit (ICU) Nurses: Results of a national survey. International Journal Of Nursing Studies 2012;49:292-9.

20. Jackson D, Firtko A, Edenborough M. Personal resilience as a strategy for surviving and thriving in the face of workplace adversity: a literature review. J Adv Nurs 2007;60:1-9.

21. Gito $M$, Ihara $H$, Ogata $H$. The relationship of resilience, hardiness, depression and burnout among japanese psychiatric hospital nurses. Journal of Nursing Education and Practice 2013;3:11.

22. McAllister $M$, McKinnon J. The importance of teaching and learning resilience in the health disciplines: a critical review of the literature. Nurse Educ Today 2009;29:371-9.

23. Matos PS, Neushotz LA, Griffin MT, Fitzpatrick JJ. An exploratory study of resilience and job satisfaction among psychiatric nurses working in inpatient units. Int J Ment Health Nurs 2010;19:307-12.

24. Karaırmak Ö. Psikolojik sağlamlık, risk faktörleri ve koruyucu faktörler. Türk Psikolojik Danışma ve Rehberlik Dergisi 2006;26:129-42.

25. Cameron F, Brownie S. Enhancing resilience in registered aged care nurses. Australas J Ageing 2010;29:66-71.

26. McDonald G, Jackson D, Wilkes L, Vickers MH. A work-based educational intervention to support the development of personal resilience in nurses and midwives. Nurse Educ Today 2012;32:378-84.

27. Büyükbayram A. Hemşirelerin iş doyumunda duygusal zekânın rolü. [Yayınlanmamış yüksek lisans tezi] İzmir: Ege Üniversitesi Sağlık Bilimleri Enstitüsü 2009.

28. Acar F. Duygusal zekâ yeteneklerinin göreve yönelik ve insana yönelik liderlik davranışları ile ilişkisi: Banka şube müdürleri üzerine bir alan araştırması. [Yayınlanmamış doktora tezi] İstanbul: İstanbul Üniversitesi 2001.

29. Bar-On R, Brown JM, Kirkcaldy BD, Thome EP. Emotional expression and implications for occupational stress; An application of the emotional quotient inventory (EQ-i). Personality and Individual Differences 2000;28:1107-18.

30. Freshman B, Rubino L. Emotional intelligence: a core competency for health care administrators. Health Care Manag (Frederick) 2002;20:1-9.

31. Tugade Michele M, Fredrickson BL, Feldman LB. Psychological resilience and positive emotional granularity: Examining the benefits of positive emotions on coping and health. Published in Final Edited Form As: J Pers 2004;72:1161-90. 
32. Salazar Cuadra D, Ferrer Famadico . Male nursıng students' emotıonal Intellıgence, carıng behavıor and resilıence. International Journal Of Arts \& Science 2013;6:243-60.

33. Gizir CA. Psikolojik sağlamlık, risk faktörleri ve koruyucu faktörler üzerine bir derleme çalışması. Türk Psikolojik Danışma ve Rehberlik Dergisi 2007;3:113.

34. Karaırmak Ö, Siviş Çetinkaya R. The Effect of Self-Esteem and Locus of Control on Resilience: The Mediating Role of Affects. Türk Psikolojik Danışma ve Rehberlik Dergisi 2011;4:30-43.

35. Güloğlu B, Karaırmak Ö. Self-esteem and Resilience as the Predictors of Loneliness among University Students. Ege Eğitim Dergisi 2010;2:73-88.

36. Zeidner M, Matthews G, Roberts R. Emotional intelligence in the workplace: A critical review. Applied psychology: An International Review 2004;53:371-39.

37. McQueen AC. Emotional intelligence in nursing work. J Adv Nurs 2004;47:101-8

38. Augusto Landa JM, López-Zafra E, Berrios Martos MP, Aguilar-Luzón Mdel C. The relationship between emotional intelligence, occupational stress and health in nurses: a questionnaire survey. Int J Nurs Stud 2008;45:888901

39. Akerjordet $\mathrm{K}$, Severinsson E. Emotional intelligence in mental health nurses talking about practice. Int J Ment Health Nurs 2004;13:164-70.

40. Güleryüz G, Güney S, Aydin EM, Aşan O. The mediating effect of job satisfaction between emotional intelligence and organisational commitment of nurses: a questionnaire survey. Int J Nurs Stud 2008;45:1625-35.

41. Lee $M$, Lee $S$. The Influence of emotional Intelligence and organizational climate for nurse job satisfaction. Journal of Business Administration
2008;4:1-10.

42. Goleman D. Duygusal zeka. Seçkin Yüksel B. (Çev.) Varlık Yayınları A.Ş. Kurtiş Matbaası. Sayı: 602. 19. Baskı. İstanbul 2001.

43. Seo SK, Kim M, Park J. Effects of resilience and job satisfaction on organizational commitment in korean-american registered nurses. J Korean Acad Nurs Adm 2014;20:48-58.

44. Öz F, Hiçdurmaz D. Stresle başetmede önemli bir yol: Mizahın kullanımı. Anadolu Hemşirelik ve Sağlık Bilimleri Dergisi 2010;13:1.

45. Abel MH. Humor, stress, and coping strategies. Humor 2002;15:365-81

46. Yılmaz M. Duygusal zeka düşünme becerileri eğitiminin annelerin duygusal zeka düzeyine etkisi. [Yayınlanmamış doktora tezi] Samsun: Ondokuz Mayıs Üniversitesi, Sosyal Bilimler Enstitüsü 2002.

47. Yılmaz $M$. The effects of an emotional intelligence skills training program on the consistent anger levels of turkish university students. Social Behavior and Personality (ISI) 2009;37:565-76.

48. Karahan FT, Özçelik M. Bir duygusal zeka beceri eğitimi programının diyabet hastalarının duygusal zeka düzeylerine etkisi. On Dokuz Mayıs Üniversitesi Eğitim Fakültesi Dergisi 2006;19:301-20.

49. Tufan Ş. Geliştirilen duygusal zeka eğitimi programının ortaöğretim dokuzuncu sınıf öğrencilerinin duygusal zeka düzeylerine etkisi. [Yayınlanmamış yüksek lisans tezi] Ankara: Ankara Üniversitesi Eğitim Bilimleri Enstitüsü. Eğitimde Psikolojik Hizmetler Anabilim Dalı Rehberlik Ve Psikolojik Danışmanlık Programı 2011.

50. Özçelik M. Duygusal zeka becerileri eğitimi programının şehit ailelerinin depresyon ve anksiyete düzeylerine etkisi. [Yayınlanmamış doktora tezi] Ondokuz Mayıs Üniversitesi Sosyal Bilimler Enstitüsü Eğitim Bilimleri Anabilim Dalı 2007. 